\title{
PRODUKSI DAN PENDAPATAN PETANI TEMBAKAU MADURA: SEBUAH KAJIAN DAMPAK PERUBAHAN IKLIM
}

\author{
Production And Revenue Of Madura Tobacco Farmers: A Study Of The Impact Of \\ Climate Change \\ Kustiawati Ningsih ${ }^{1}$ \\ ${ }^{1}$ Program Studi Agribisnis, Fakultas Pertanian, Universitas Islam Madura, \\ Kompleks Ponpes Miftahul Ulum Bettet, Pamekasan, Madura, Kode Pos 69351, \\ Indonesia \\ E-mail : kustiawatin@gmail.com
}

\begin{abstract}
ABSTRAK
Kecamatan Pakong memiliki potensi di bidang pertanian tanaman perkebunan yaitu kelapa dan tembakau. Berdasarkan data BPS Kabupaten Pamekasan, pada tahun 2016, tanaman tembakau di Kecamatan Pakong menduduki peringkat ketiga luas panen dan produksi terbesar setelah Kecamatan Waru dan Kecamatan Pagentenan dengan luas panen 368 ha dan produksi sebesar 193,15 ton. Hal ini menunjukkan bahwa Kecamatan Pakong memiliki potensi dalam usaha tani tembakau dan juga dapat meningkatkan pendapatan petani. Tembakau Madura merupakan pendapatan petani yang cukup besar di daerah Kabupaten Pamekasan khususnya di Kecamatan Pakong. Perkembangannya yang di pengaruhi oleh cuaca secara tidak langsung akan mempengaruhi produksi dan pendapatan petani tembakau Madura sehingga diperlukan penelitian bagaimana dampak perubahan cuaca atau iklim terhadap produksi dan pendapatan petani tembakau Madura. Sehingga tujuan penelitian ini adalah untuk menganalisis dampak perubahan iklim terhadap produksi dan pendapatan petani tembakau Madura. Metode analisis data menggunakan analisis biaya usaha tani tembakau Madura, analisis penerimaan usaha tani tembakau Madura, analisis pendapatan usaha tani tembakau Madura serta analisis uji beda rata-rata menggunakan uji wilcoxon. Hasil penelitian menunjukkan bahwa dampak perubahan iklim terhadap biaya usaha tani tembakau menyebabkan biaya usaha tani menurun dari tahun 2015 ke tahun 2016 yaitu dari Rp. 3.327.100,- menjadi Rp. 3.137.881,5,- . demikian juga dengan penerimaan usaha tani tembakau Madura juga mengalami penurunan dari tahun $2015 \mathrm{ke}$ tahun 2016 yaitu dari Rp 12.126.370,- menjadi Rp 9.296.700,-. Sehingga secara langsung pendapatan usaha tani tembakau Madura juga mengalami penurunan dari tahun 2015 ke tahun 2016 yaitu dari Rp. 8.799.270,- menjadi Rp. 6.158.818,5,-. Hasil uji beda rata-rata menunjukkan bahwa dari 41 petani responden, 40 diantaranya mengalami penurunan pendapatan, dan 1 petani responden mengalami peningkatan dikarenakan petani tetap melakukan penanaman pada bulan Mei walaupun pada tahun 2016 intensitas curah hujan tinggi, sedangkan yang tetap tidak ada.
\end{abstract}

Kata Kunci : Tembakau Madura, Produksi, Pendapatan, Perubahan Iklim

\section{ABSTRACT}

Pakong Subdistrict has potential in agricultural plantations, namely coconut and tobacco. Based on Pamekasan Regency BPS data, in 2016, tobacco plants in Pakong Subdistrict were ranked as the third largest harvest and production area after Waru and Pagentenan Districts with a harvest area of 368 ha and production of 193.15 tons. This shows that Pakong Subdistrict has potential in tobacco farming and can also increase 
farmers' income. Madura Tobacco is a large income of farmers in the Pamekasan Regency, especially in Pakong District. Its development influenced by weather will indirectly affect the production and income of Madura tobacco farmers, so research is needed on the impact of climate change or climate on the production and income of Madura tobacco farmers. So the purpose of this study was to analyze the impact of climate change on the production and income of Madura tobacco farmers. The method of data analysis used the analysis of the cost of Madura tobacco farming, analysis of receipt of Madura tobacco farming, analysis of income of Madura tobacco farming and analysis of the average difference test using the Wilcoxon test. The results showed that the impact of climate change on the costs of tobacco farming caused the cost of farming to decline from 2015 to 2016, namely from $R p$. 3,327,100, - to $R p$. 3,137,881.5, -. Likewise, the acceptance of Madura tobacco farming business also decreased from 2015 to 2016, from $R p$. 12,126,370 to $R p$ 9,296,700. So that directly the income of Madura tobacco farming also decreased from 2015 to 2016, namely from $R p$. 8,799,270, - to $R p .6,158,818.5$, -. The average difference test results showed that from 41 respondents, 40 of them experienced a decline in income, and 1 respondent farmer experienced an increase because farmers continued to plant in May even though in 2016 the intensity of rainfall was high, while those that remained did not exist.

Keywords: Madura Tobacco, Production, Income, Climate Change

\section{PENDAHULUAN}

Tembakau merupakan salah satu komoditas perdagangan penting di Indonesia. Produk tembakau yang utama diperdagangkan adalah daun tembakau dan rokok. Tembakau dan rokok merupakan produk yang bernilai tinggi, sehingga bagi beberapa negara termasuk Indonesia berperan dalam perekonomian nasional, yaitu sebagai salah satu sumber devisa, sumber penerimaan pemerintah dan pajak (cukai), sumber pendapatan para petani dan lapangan kerja masyarakat (usaha tani dan pengolahan rokok).

Kecamatan Pakong memiliki
potensi di bidang pertanian tanaman

perkebunan yaitu kelapa dan tembakau.

Berdasarkan data BPS Kabupaten Pamekasan, pada tahun 2016, tanaman tembakau di Kecamatan Pakong menduduki peringkat ketiga luas panen dan produksi terbesar setelah Kecamatan Waru dan Kecamatan Pagentenan dengan luas panen 368 ha dan produksi sebesar 193,15 ton. Hal ini menunjukkan bahwa Kecamatan Pakong memiliki potensi dalam usaha tani tembakau dan juga dapat meningkatkan pendapatan petani. Luas areal tanaman perkebunan dan produksi tanaman perkebunan di Kecamatan Pakong Tahun 2014, 2015, 2016 bisa di lihat pada Tabel 1 di bawah ini. 
Tabel 1. Luas areal tanam dan produksi tanaman perkebunan di Kecamatan Pakong tahun 2014, 2015, 2016.

\begin{tabular}{|c|c|c|c|c|}
\hline \multirow{2}{*}{ Tahun } & \multicolumn{2}{|c|}{ Luas areal tanam (ha) } & \multicolumn{2}{c|}{ Produksi (ton) } \\
\cline { 2 - 5 } & Tembakau & Kelapa & Tembakau & Kelapa \\
\hline 2014 & 354 & 71 & 183.130 & 103,94 \\
\hline 2015 & 365 & 84 & 193,15 & 196,07 \\
\hline 2016 & 368 & 84 & 193,15 & 196,07 \\
\hline
\end{tabular}

Sumber : BPS Kabupaten Pamekasan 2016

Tabel 1 menunjukkan produksi kenaikan gas-gas rumah kaca terutama tanamanan tembakau menurun pada tahun karbondioksida $(\mathrm{CO} 2)$ dan metana $(\mathrm{CH} 4)$, 2014-2016. Tahun 2014, produksi mengakibatkan dua hal utama yang terjadi tembakau mencapai 183.130 ribu ton di lapisan atmosfer paling bawah, yaitu dengan luas areal tanam 354 ha, fluktuasi curah hujan yang tinggi dan sedangkan pada tahun 2015 sampai 2016 kenaikan muka laut. Sebagai negara produksi tembakau menurun drastis yang kepulauan, Indonesia paling rentan mulanya dari luas areal tanam 354 ha terhadap kenaikan muka laut. Telah menghasilkan 183.130 ton menurun dilakukan proyeksi kenaikan muka laut menjadi 193,15 ton dari luas areal tanam untuk wilayah Indonesia, hingga tahun 368 ha. 2021, diperkirakan adanya kenaikan muka

Pada sektor pertanian dampak laut hingga $1.1 \mathrm{~m}$ yang yang berdampak perubahan iklim yang paling nyata adalah kerusakan (degradasi) dan penurunan pada hilangnya daerah pantai dan pulaupulau kecil seluas $90.260 \mathrm{~km} 2$ (Susandi kualitas sumberdaya lahan dan air, et-all, 2008). infrastruktur pertanian, penurunan

Para petani bingung menghadapi produksi dan produktivitas tanaman perubahan iklim karena hujan tidak pangan, yang akan menghasilkan ancaman kunjung berhenti, misalnya tembakau kerena tanaman dan kerawanan terhadap milik petani di Kecamatan Pakong rusak ketahanan pangan dan bahkan akibat terlalu banyak hujan. Informasi kemiskinan. Hal tersebut dapat iklim sangat dibutuhkan petani namun meningkatkan risiko usaha tani, baik informasi ramalan cuaca kebanyakan tidak pangan, perkebunan, peternakan, maupun hortikultura. (Putri \& Suryanto, 2012).

Perubahan iklim sebagai implikasi pemanasan global, yang disebabkan oleh akurat dan petani tidak mendapatkan informasi tersebut.

Tembakau di Kecamatan Pakong tergolong tembakau musim kemarau 
(Voor-Oogst) yang digunakan sebagai bahan membuat rokok kretek dan filter. Masa penanaman tanaman tembakau di Kecamatan Pakong diperkirakan masa tanam pada pertengahan bulan April sampai dengan akhir bulan Mei. Lahan tersebut terus disterilkan dari gangguan rumput-rumput liar di sekitar tanaman sampai tembakau tersebut berbunga. Tanaman tembakau akan terlihat baik apabila pada waktu penanaman di musim hujan, hal itu akan membantu pertumbuhan tanaman agar cepat tumbuh dan berkembang. Semakin kering lahan kondisi lahan, semakin baik tembakau yang dihasilkan.

Tembakau Madura merupakan pendapatan petani yang cukup besar di daerah Kabupaten Pamekasan khususnya di Kecamatan Pakong. Perkembangannya yang di pengaruhi oleh cuaca secara tidak langsung akan mempengaruhi produksi dan pendapatan petani tembakau Madura sehingga diperlukan penelitian bagaimana dampak perubahan cuaca atau iklim terhadap produksi dan pendapatan petani tembakau Madura.

\section{TUJUAN PENELITIAN}

Penelitian ini bertujuan untuk menganalisis dampak perubahan iklim terhadap produksi dan pendapatan petani tembakau Madura.

\section{METODE PENELITIAN}

\section{a. Lokasi dan Waktu Penelitian}

Penelitian ini dilakukan di Kecamatan Pakong, Kabupaten Pamekasan. Pemilihan lokasi tersebut dilakukan secara sengaja (purposive) dengan pertimbangan bahwa Kecamatan Pakong merupakan salah satu sentra produksi tembakau Madura di Kabupaten Pamekasan. Penelitian ini dilakukan bulan Juni dan Juli Tahun 2016.

\section{b. Jenis Data}

Data yang digunakan adalah data primer dan data sekunder. Data primer diperoleh dari pengamatan di lapangan dan wawancara dengan petani tembakau Madura yang meliputi jumlah input dan biayanya, jumlah output beserta harga jualnya. Semua data primer dikumpulkan dengan cara survei, dan mewawancarai responden secara langsung dengan menggunakan daftar pertanyaan (kuisioner) yang telah dipersiapkan sebelumnya (Singarimbun dan Effendi, 1987). Sedangkan data sekunder diperoleh dari Departemen Kehutanan dan Perkebunan Kabupaten Pamekasan, perpustakaan UIM 
Pamekasan dan instansi-instansi terkait lainnya.

\section{c. Metode Penentuan Sampel}

Metode pengambilan sampel dalam penelitian ini menggunakan metode simple random sampling dimana tiap unsur yang membentuk populasi di beri kesempatan yang sama untuk terpilih menjadi sampel. Untuk menentukan ukuran sampel diambil dari pendekatan jumlah populasi dengan menggunakan formula slovin sebagai berikut :

$$
\mathrm{n}=\frac{N}{1+N(e)^{2}}
$$

Dimana :

$\mathrm{N}=$ jumlah populasi

e = kesalahan yang diharapkan peneliti

$\mathrm{n}$ = jumlah sampel yang diambil

Sesuai dengan rumus slovin yang telah diurai sebelumnya, maka jumlah populasi yang akan diambil dengan tingkat kesalahan $15 \%$ dalam penelitian ini adalah :

$$
\begin{aligned}
& \mathrm{n}=\frac{540}{1+540(15 \%)^{2}} \\
& \mathrm{n}=\frac{540}{1+540(0,0225)^{2}} \\
& \mathrm{n}=\frac{540}{1+12,15} \\
& =41 \text { petani }
\end{aligned}
$$

Populasi ini berdasarkan petani yang menanam tembakau pada lahan tegal dan sawah. Total populasi petani tembakau Madura di Kecamatan Pakong adalah sebesar 540 orang. Sehingga dari total populasi 540 petani tersebut diambil 41 petani responden yang ditentukan dengan menggunakan rumus slovin dengan tingkat kesalahan $15 \%$.

\section{d. Metode Analisis Data}

\section{Analisis Biaya Usaha tani Tembakau \\ Madura}

Biaya usaha tani merupakan total biaya tetap yang meliputi penyusutan peralatan dan sewa lahan, serta biaya variabel seperti biaya benih, pupuk, pestisida dan tenaga kerja per hektar dalam satu kali musim tanam yang digunakan dalam usaha tani tembakau. Besarnya biaya produksi dapat dihitung sebagai berikut :

$\mathrm{TC}=\mathrm{TFC}+\mathrm{TVC}$

Dimana:

TC = Biaya Total (total cost)

TFC = Biaya Tetap (Total fixed cost)

TVC = Biaya Variabel (Total variable $\cos t)$

\section{Analisis Penerimaan Usaha tani Tembakau Madura}

Penerimaan usaha tani adalah perkalian antara jumlah produksi tembakau yang dihasilkan per hektar dalam satu kali musim tanam dengan 
harga jualnya per produksi. Besar penerimaan yang diterima dipengaruhi oleh besarnya produksi usaha tani serta harga jual per produk. Penerimaan usaha tani tembakau dapat dihitung dengan menggunakan rumus sebagai berikut:

$$
\mathrm{TR}=\mathrm{P} \cdot \mathrm{Q}
$$

Dimana:

$$
\begin{array}{ll}
\mathrm{TR} & =\text { Penerimaan usaha tani } \\
\mathrm{P} & =\text { Harga produksi } \\
\mathrm{Q} & =\text { Hasil produksi }
\end{array}
$$

Analisis Pendapatan Usaha tani

\section{Tembakau Madura}

Pendapatan usaha tani tembakau adalah selisih antara penerimaan dari penjualan hasil produksi tembakau yang di dapat dengan total biaya yaitu biaya tetap dan variabel yang dikeluarkan selama kegiatan usaha tani berlangsung dalam satu musim tanam. Besarnya pendapatan usaha tani tembakau dapat dihitung dengan menggunakan rumus sebagai berikut :

$$
\pi=\mathrm{TR}-\mathrm{TC}
$$

Dimana:

$$
\begin{aligned}
& \pi \quad=\text { Pendapatan } \\
& \mathrm{TR}=\text { Total penerimaan (total } \\
& \text { revenue) } \\
& \mathrm{TC}=\text { Total biaya (fixed cost) }
\end{aligned}
$$

\section{Analisis Uji Beda Rata-Rata}

Uji perbedaan tentang pengetahuan dan sikap petani terhadap produksi usaha tani tembakau tahun 2015 dan 2016 menggunakan software spss16. Analisis yang digunakan adalah analisis uji beda rata-rata dengan cara :

\section{a. Merumuskan Hipotesis Statistik}

Rumusan statistik yang dimaksud adalah sebagai berikut :

$\mathrm{H}_{0}: \mu_{1} \leq \mu_{2}$ : Jika tidak terdapat perbedaan pada nilai rata-rata produksi usaha tani tembakau tahun 2015 dan 2016. $\mathrm{H}_{1}: \mu_{1}>\mu_{2}$ : Jika terdapat perbedaan pada nilai rata-rata produksi usaha tani tembakau tahun 2015dan tahun 2016.

Dimana :

$\mu_{1}=$ nilai rata-rata produksi tembakau pada tahun 2015

$\mu_{2}=$ nilai rata-rata produksi tembakau pada tahun 2016

\section{b. Pengujian Hipotesis Dengan Taraf} Kepercayaan 95\% Atau A $=\mathbf{0 , 0 5}$

sebelum mencari $t_{\text {hitung }}$ terlebih dahulu menghitung S1 dan S2:

$$
\begin{aligned}
& \mathrm{s}_{1}^{2}=\frac{\sum(X i-X 1)^{2}}{\left(\mathrm{n}_{2}-1\right)} \\
& \mathrm{s}_{2}^{2}=\frac{\sum(X i-X 2)^{2}}{\left(\mathrm{n}_{2}-1\right)}
\end{aligned}
$$


Dimana :

$\mathrm{s}_{1}^{2} \quad=$ nilai varian dari produksi usaha tani tembakau pada tahun 2015

$\mathrm{s}_{2}^{2} \quad=$ nilai varian dari produksi usaha tani tembakau pada tahun 2016

$\mathrm{Xi}=$ contoh ke- $\mathrm{i}$

$\mathrm{X} 1=$ rata-rata hitung untuk sampel pengetahuan dan sikap petani tembakau terhadap produksi usaha tani tembakau pada tahun 2015

X2 = rata-rata hitung untuk sampel produksi usaha tani tembakau pada tahun 2016

$\mathrm{n} 1=$ jumlah sampel dari petani tembakau tahun 2015

$\mathrm{n} 2=$ jumlah sampel dari petani tembakau tahun 2016

Setelah S1 dan S2 diketahui, dilanjutkan dengan rumus yang digunakan adalah :

$$
\mathrm{F} \text { hitung }=\frac{\mathrm{s}_{1}^{2}}{\mathrm{~s}_{2}^{2}}
$$

Dengan kaidah pengujian:

1) Bila F hitung > F tabel $0,05(\mathrm{n} 1=1),(\mathrm{n} 2$ = 1) berarti varian berbeda nyata, sehingga untuk menguji hipotesis digunakan uji t dengan rumus:

$\mathrm{T}$ hitung $=\frac{x 1-x 2}{\sqrt{\frac{s 1}{n 1}}+\frac{s 2}{n 2}}$
2) Bila $F$ hitung $>F$ tabel $0,05(n 1=1),(n 2$ $=1$ ) berarti varian sama, sehingga untuk menguji hipotesis digunakan uji t dengan rumus:

$$
\text { Thitung }=\frac{x 1-x 2}{\sqrt{\left(s_{2}\left(\frac{1}{n 1}+\frac{1}{n 2}\right)\right)}}
$$

$$
\begin{aligned}
& s^{2} \\
& =\frac{(n 1-1) s_{1}^{2}+(n 2-1) s_{2}^{2}}{(n 1-1)+(n 2-1)}
\end{aligned}
$$

Dengan ketentuan:

a. Bila T hitung > T tabel 0,05 $(n 1=1+$ $n 2=2)$ maka $\mathrm{H} 1$ diterima dan tolak $\mathrm{H} 0$ artinya ada perbedaan yang nyata.

b. Bila $\mathrm{T}$ hitung $<\mathrm{T}$ tabel $0,05(n 1=1+$ $n 2=2)$ maka H0 diterima dan tolak H1 artinya tidak ada perbedaan yang nyata.

\section{HASIL PENELITIAN DAN PEMBAHASAN}

\section{Sikap Petani Terhadap Perubahan \\ Iklim}

Adanya perubahan iklim telah menimbulkan dampak yang sangat besar pada usaha tani tembakau di Indonesia, khususnya di lokasi yang saya teliti. Hal tersebut menimbulkan sikap dan tindakan yang nyata yang di lakukan oleh petani.

Perubahan iklim yang ditandai dengan sering turun hujan sepanjang 
tahun 2016 membuat 25 petani responden menambah perlakuan atau perawatan pada tanaman tembakau di lahan, mereka sadar dan mengetahui adanya perubahan iklim. Sikap positif ini ditunjukkan dengan melakukan tindakan nyata berupa perawatan yang lebih pada tanaman tembakau karena berharap agar lebih baik dari kondisi yang semula kurang bagus. Perlakuan tersebut antara lain : penanaman yang lebih awal, penyulaman tanaman, penyemprotan pupuk, lebih sering melakukan penyiangan, membuang ulat daun ada juga yang memakai obat agar tidak dimakan ulat daun tembakau, dengan perlakuan-perlakuan tersebut, petani mampu mempertahankan kondisi tanaman tembakaunya namun petani yang menanam awal merasa lebih ringan dikarenakan mereka tidak perlu sering menyiram tembakaunya karena sudah terkena hujan. Adapun sikap petani bisa dilihat pada tabel di bawah ini.

Tabel 2. Sikap Responden Terhadap Perubahan Iklim Di Kecamatan Pakong

\begin{tabular}{|l|c|c|}
\hline \multicolumn{1}{|c|}{ Sikap petani } & $\begin{array}{c}\text { Jumlah respoden } \\
\text { (orang) }\end{array}$ & Persentase (\%) \\
\hline Menambah perlakuan & 25 & 61 \\
\hline Penundaan penanaman & 10 & 24 \\
\hline Tidak menanam & 6 & 15 \\
\hline Jumlah & 41 & 100 \\
\hline
\end{tabular}

Sumber: Data primer diolah, 2017

Selanjutnya, dari 41 responden 10 tersebut menjadi penyebab petani diantaranya melakukan penundaan tembakau gagal panen karena pada saat penanaman biasanya penanaman tembakaunya sudah tua bisa dikatakan tembakau dilakukan pada bulan Mei, sudah siap dipanen malah terjadi hujan namun mereka menunda waktu terus menerus sehingga tanaman penanaman pada bulan Juni. Hal tersebut tembakau petani rusak dan gagal panen. dilakukan karena petani masih menunggu tidak turunnya hujan. Anggapan petani Sedangkan responden yang menunda waktu penanaman tersebut supaya hasil tembakaunya tidak terkena hujan, namun penundaan penanaman terakhir petani yang jumlahnya 6 orang dari 41 responden memutuskan untuk tidak menanam tembakau dikarenakan mereka melihat cuaca yang kurang bagus 
biasanya pada bulan Mei intensitas curah hujan rendah namun pada tahun 2016 intensitas curah hujan masih tinggi sehingga petani enggan untuk menanam tembakau, mereka memilih lahannya tidak ditanami tanaman apapun.

Dampak Perubahan Iklim Terhadap Produksi Dan Harga Tembakau
Produksi usaha tani tembakau merupakan hasil panen yang diperoleh dalam satu kali musim tanam tembakau. Dari hasil penelitian pada musim tanam tahun 2015 ke tahun 2016, menunjukkan bahwa adanya penurunan produksi tembakau. Penurunan tersebut dapat dilihat pada tabel di bawah ini.

Tabel 3. Jumlah Rata-Rata Produksi Dan Harga Tembakau Dari 41 Responden Di Kecamatan Pakong

\begin{tabular}{|c|c|c|}
\hline \multirow{2}{*}{ Uraian } & \multicolumn{2}{|c|}{ Jumlah } \\
\cline { 2 - 3 } & Tahun 2015 & Tahun 2016 \\
\hline Produksi & $319,115 \mathrm{~kg}$ & $265,620 \mathrm{~kg}$ \\
\hline Harga & Rp $38.000,-$ & Rp $35.000,-$ \\
\hline
\end{tabular}

Sumber: Data primer diolah, 2017

Dilihat dari Tabel 3 di atas, dapat awalnya pada tahun 2015 rata-rata dalam disimpulkan bahwa perubahan iklim 1kg mencapai $\mathrm{Rp} 38.000$ menurun berpengaruh terhadap jumlah produksi menjadi Rp 35.000 per kg di tahun 2016. tembakau, curah hujan yang tinggi menyebabkan produksi tembakau yang semula mecapai $319,115 \mathrm{~kg}$ di tahun 2015 turun menjadi 265,620 kg di tahun 2016, atau terjadi penurunan produksi sebesar 53,49\%. Meskipun pada tahun 2016 produksi tembakau menurun hukum permintaan disini tidak berlaku dikarenakan tembakau petani terkena hujan sehingga kualitas tembakau kurang baik sehingga menyebabkan harga tembakau juga ikut menurun yang

\section{Dampak Perubahan Iklim Terhadap}

\section{Pendapatan Petani Tembakau}

\section{Analisis Biaya Usaha tani Tembakau}

Biaya usaha tani adalah biaya yang dikeluarkan oleh petani tembakau dalam satu kali musim, biaya produksi ini terdiri dari biaya tetap dan biaya variabel. Untuk mengetahui biaya total (TC) yaitu dengan cara biaya tetap (TFC) dijumlahkan dengan biaya variabel (TVC). Untuk lebih jelasnya dapat dilihat pada tabel dibawah ini. 
Tabel 4. Jumlah Rata-Rata Biaya Usaha tani Tembakau Dari 41 Responden Di Kecamatan Pakong Kabupaten Pamekasan

\begin{tabular}{|l|l|l|}
\hline \multirow{2}{*}{ Uraian biaya } & \multicolumn{2}{c|}{ Jumlah } \\
\cline { 2 - 3 } & \multicolumn{1}{c|}{ Tahun 2015 (Rp) } & Tahun 2016 (Rp) \\
\hline Biaya tetap (TFC) & 605.250 & $595.450,5$ \\
\hline Biaya variabel (TVC) & 2.721 .850 & 2.542 .431 \\
\hline Biaya total (TC) & 3.327 .100 & $3.137 .881,5$ \\
\hline
\end{tabular}

Sumber: Data primer diolah, 2017

Pada Tabel 4 di atas, menginformasikan bahwa terjadi penurunan biaya total produksi tembakau di lokasi penelitian. Jika pada tahun 2015, biaya total mencapai Rp 3.327.100,-, maka menurun menjadi Rp 3.137.881,5,- pada tahun 2016. Hal tersebut disebabkan berkurangnya jumlah petani yang menanam tembakau, sehingga harga pupuk menurun dikarenakan permintaan pupuk berkurang.

\section{Analisis Penerimaan Usaha tani}

\section{Tembakau Madura}

Penerimaan usaha tani tembakau Madura dapat diperoleh dari hasil produksi tembakau dikalikan harga jual tembakau. Dari hasil penelitian pada tahun 2015 dan 2016, menunjukkan adanya penurunan penerimaan petani tembakau Madura. Penurunan tersebut dapat di buktikan dari Tabel 5.

Tabel 5. Jumlah Rata-Rata Penerimaan Usaha tani Tembakau Dari 41 Responden di Kecamatan Pakong Kabupaten Pamekasan

\begin{tabular}{|c|c|c|}
\hline \multirow{2}{*}{ Uraian } & \multicolumn{2}{|c|}{ Jumlah } \\
\cline { 2 - 3 } & Tahun 2015 & Tahun 2016 \\
\hline Produksi & $319,115 \mathrm{~kg}$ & $265,620 \mathrm{~kg}$ \\
\hline Harga & $\mathrm{Rp} 38.000,-$ & $\mathrm{Rp} 35.000,-$ \\
\hline Penerimaan & $\mathrm{Rp} 12.126 .370,-$ & $\mathrm{Rp} 9.296 .700,-$ \\
\hline
\end{tabular}

Sumber: Data primer diolah, 2017

Berdasarkan Tabel 5 di atas, dapat $\mathrm{Rp}$ 9.296.700,-. Hal itu dipicu dari disimpulkan bahwa penerimaan total berkurangnya petani menanam tembakau responden menurun dari tahun 2015 ke yang awalnya pada tahun 2015 dari 41 tahun 2016. Jika pada tahun 2015 rata-rata responden menanam semua namun pada penerimaan dari 41 responden petani tahun 2016 tinggal 25 orang namun dari sebesar Rp 12.126.370,- maka pada tahun 25 tersebut ada 10 orang yang gagal panen 2016 penerimaan petani menurun menjadi dan mereka juga mengurangi jumlah 
tanam tembakau sisanya tidak menanam tembakau.

\section{Analisis Pendapatan Usaha tani}

\section{Tembakau Madura}

Pendapatan usaha tani tembakau adalah selisih antara penerimaan (TR) dari penjualan hasil produksi tembakau yang di dapat dengan biaya total (TC) yang dikeluarkan selama kegiatan usaha tani berlangsung dalam satu musim tanam. Total penerimaan dikurangi total biaya. Dari hasil perhitungan diperoleh bahwa pendapatan petani tembakau menurun dari tahun 2015 ke tahun 2016. Pendapatan petani tembakau ketika tahun 2015 mencapai Rp 8.799.270,- menurun menjadi Rp 6.158.818,5,- pada tahun 2016. Penurunan pendapatan petani tersebut karena berkurangnya petani menanam tembakau sehingga produksi tembakau lebih sedikit dibandingkan tahun sebelumnya. Penurunan tersebut dapat dibuktikan pada tabel di bawah ini.

Tabel 6. Jumlah Rata-Rata Pendapatan Petani Tembakau Dari 41 Responden Di Kecamatan Pakong

\begin{tabular}{|l|l|l|}
\hline \multirow{2}{*}{ Uraian } & \multicolumn{2}{|c|}{ Jumlah } \\
\cline { 2 - 3 } & \multicolumn{1}{|c|}{ Tahun 2015(Rp) } & \multicolumn{1}{c|}{ Tahun 2016 (Rp) } \\
\hline Penerimaan & 12.126 .370 & 9.296 .700 \\
\hline Biaya total & 3.327 .100 & $3.137 .881,5$ \\
\hline Pendapatan & 8.799 .270 & $6.158 .818,5$ \\
\hline
\end{tabular}

Sumber: Data primer diolah, 2017

Analisis Uji Rata-Rata Pendapatan

\section{Petani Tembakau}

Pengujian ini dilakukan untuk mengetahui apakah ada perbedaan antara pendapatan petani tembakau pada tahun 2015 dan 2016, dengan menggunakan taraf signifikansi, $\alpha=5 \%$ atau $\alpha=0,05$, alat analisis yang digunakan dalam analisis uji beda rata-rata adalah uji wilcoxon. Hasil dari pengujian dengan menngunakan uji wilcoxon dapat dilihat pada Tabel 7. 
Tabel 7. Hasil Uji Wilcoxon

Ranks

\begin{tabular}{|l|l|l|l|l|}
\hline & & N & Mean Rank & Sum of Ranks \\
\hline p2016 - p2015 & Negative Ranks & $39 \mathrm{a}$ & 21.00 & 819.00 \\
\cline { 2 - 5 } & Positive Ranks & $1 \mathrm{~b}$ & 1.00 & 1.00 \\
\hline & Ties & $0 \mathrm{c}$ & & \\
\cline { 2 - 5 } & Total & 40 & & \\
\hline
\end{tabular}

a. $\mathrm{p} 2016<\mathrm{p} 2015$

b. $\mathrm{p} 2016>$ p2015

c. $\mathrm{p} 2016=\mathrm{p} 2015$

Tabel 7.1. Hasil Uji Wilcoxon

Test Statisticsb

\begin{tabular}{|l|l|}
\hline & $\mathrm{p} 2016-\mathrm{p} 2015$ \\
\hline$Z$ & $-5.498 \mathrm{a}$ \\
\hline Asymp. Sig. (2-tailed) & .000 \\
\hline
\end{tabular}

a. Based on positive ranks.

b. Wilcoxon Signed Ranks Test

Berdasarkan uji wicoxon pada dapat dinyatakan bahwa tolak H0 dan Tabel di atas, dapat diketahui bahwa dari terima $\mathrm{H} 1$, yang berarti terdapat 41 petani responden, 40 diantaranya perbedaan signifikan antara pendapatan mengalami penurunan pendapatan, dan 1 petani responden mengalami peningkatan dikarenakan petani tetap melakukan penanaman pada bulan Mei walaupun pada tahun 2016 intensitas curah hujan tinggi, sedangkan yang tetap tidak ada . Hasil uji wilcoxon pada Tabel di atas juga diperoleh nilai signifikansi sebesar $\alpha=$ 0,000. Oleh karena itu taraf signifikansi $(\alpha)$ pada perhitungan lebih kecil dari taraf signifikansi $(\alpha)$ yang ditetapkan yaitu 5\% atau $005(0,000<0,05)$, maka dari itu petani tembakau pada tahun 2015 dengan tahun 2016 di lokasi penelitian. Sehingga dapat disimpulkan, bahwa pada tahun 2016 pendapatan petani tembakau di Kecamatan Pakong Kabupaten Pamekasan mengalami penurunan.

\section{KESIMPULAN DAN SARAN}

\section{Kesimpulan}

Berdasarkan hasil penelitian dan pembahasan, maka dapat disimpulkan bahwa sikap petani terhadap adanya 
perubahan iklim adalah: sebanyak 25 orang melakukan perawatan, 10 orang melakukan penundaan waktu tanam tembakau, dan 6 orang tidak menanam tembakau. Dampak perubahan iklim menyebabkan terjadinya penurunan produksi tembakau kualitas tembakau juga kurang bagus. Jika pada tahun 2015 ratarata produksi tembakau responden mencapai 319,115 kg, maka pada tahun 2016 menurun menjadi $265,620 \mathrm{~kg}$. Perubahan iklim tersebut berdampak pada harga tembakau juga yang awalnya pada tahun 2015 rata-rata harga tembakau sebesar Rp 38.000,- menurun menjadi $\mathrm{Rp}$ 35.000,- per kg, di tahun 2016. Dampak perubahan iklim juga menyebabkan terjadinya penurunan pendapatan petani tembakau. Jika pada tahun 2015 pendatan petani tembakau rata-rata sebesar $\mathrm{Rp}$ 8.799.270,- sedangkan pada tahun 2016 pendapatan petani menurun menjadi $\mathrm{Rp}$ 6.158.818,5,-. Diketahui bahwa dari 41 petani responden, 40 responden diantaranya mengalami penurunan pendapatan, dan 1 petani responden mengalami peningkatan dikarenakan petani tetap melakukan penanaman pada bulan Mei walaupun pada tahun 2016 intensitas curah hujan tinggi, sedangkan yang tetap tidak ada.

\section{Saran}

1. Sebaiknya petani mengambil sikap yang lebih bijak lagi atas usaha tani tembakau yang dilakukan. Pembiaran dan penundaan masa tanam tembakau bukan merupakan langkah yang tepat dalam pengambilan keputusan menanam tembakau.

2. Petani diharapkan sering menjalin komunikasi yang baik dengang penyuluh ccccpertanian, terutama yang bersangkutan dengan perubahan iklim sehingga petani dapat meminimalisir adanya penurunan produksi dan pendapatan petani.

\section{DAFTAR PUSTAKA}

Akbar, Arsyadani Fahmi. (2014). Strategi Pengembangan Kemitraan Petani Tembakau Dengan Pt Merabu Di Kecamatan Tanggungharjo Kabupaten Grobogan. Universitas Sebelas Maret. Kentingan surakarta

Dwiyanti Septi Pertiwi. (2012). Faktorfaktor yang mempengaruhi tembakau rakyat. Universitas diponegoro. Semarang.

Fitria Anisa Putri. (2012). Strategi adaptasi dampak perubahan iklim terhadap sector pertanian tembakau. Universitas sebelas maret. Surakarta.

Hermeningsih, Hesty\& Rokhani. (2014). Pengaruh Perubahan Iklim terhadap 
Perilaku Petani Tembakau di Soekartawi, John L. Dilon, J. Brian Kabupaten Jember. Vol 1 no 2.

Putri, Fitria Anisa \& Suryanto. (2012). Strategi adaptasi dampak perubahan iklim Terhadap sektor pertanian tembakau. Jurnal Ekonomi dan Studi Pembangunan. Vol 13 no 1. Hardaker, A. Soeharjo. (1986). Ilmu usahatan dan penelitian untuk perkembangan petani kecil. Universitas Indonesia (ui-pres). Salemba, Jakarta.

Sundari, Mei Tri. (2011). Analisis biaya dan pendapatan usaha tani wortel $\mathrm{Di}$ kabupaten karanganyar. Vol 7 no 2.

Rahim \& Hastuti, Diah Retno Dwi. (2007). Ekonomika pertanian. Penebar swadaya. Jakarta.

Susandi, Armi, Indriani Herlianti, Mamad Tamamadin, Irma Nurlela. (2010). Dampak Perubahan Iklim Terhadap Ketinggian Muka Laut Di Wilayah Banjarmasin. Vol 2 no 3. produksi dan pendapatan usaha tani cabai rawit. Vol 2 no 8. 